\title{
EFEKTIVITAS PEMBELAJARAN TASA WUF DALAM MENCAPAI KECERDASAN EMOSIONAL DAN SPIRITUAL DI PONDOK PESANTREN FAJAR DUNIA BOGOR
}

\author{
Devi Kurniati \\ Pendidikan Agama Islam, Fakultas Ilmu Sosial, Universitas Negeri Jakarta \\ E-mail: devikurniati_pai17s1@mahasiswa.unj.ac.id
}

Sari Narulita

Pendidikan Agama Islam, Fakultas Ilmu Sosial, Universitas Negeri Jakarta

E-mail: sarinarulita@unj.ac.id

\section{Andy Hadiyanto}

Pendidikan Agama Islam, Fakultas Ilmu Sosial, Universitas Negeri Jakarta

E-mail: andy-hadiyanto@unj.ac.id

\begin{abstract}
Article Information http://journal.unusia. ac.id/index.php/moz aicl
\end{abstract}

DOI:

10.47776/mozaic.v7i 1.173

Informasi Artikel

Naskah diterima: 15

Maret 2021

Naskah direvisi: 8 April 2021

Naskah disetujui: 24 April 2021

Naskah dipublish: 27

April 2021

\section{Keywords: Sufism, Emotional and Spiritual \\ Intelligence, Islamic} Boarding School

Kata Kunci Tasawuf, Kecerdasan Emosional dan

\begin{abstract}
Abstact
The modern world has been engulfed in a spiritual vacuum. Humans will not enjoy life if they cannot find the meaning of life, and it can only be obtained if humans have spirituality within themselves. As one of the disciplines of science in Islam, Sufism can answer the spiritual problems of modern humans. Islamic boarding schools are Islamic education institutions that still apply Sufism learning clearly in their curriculum. One of the pesantren that has emerged and made Sufism the primary plan or prior knowledge is Pondok Pesantren Fajar Dunia. This study aims to describe and analyze the effectiveness of Sufism learning in achieving emotional and spiritual intelligence at Pondok Pesantren Fajar Dunia. This study uses qualitative methods. The findings in this study indicate that the Sufism learning carried out at the Fajar Dunia Islamic Boarding School runs effectively. It refers to the indicators of achievement of the learning goals of Sufism, the learning management process of Tawasuf, the response of students to Sufism learning, and so the learning outcomes of students.
\end{abstract}

\section{Abstrak}

Dunia modern telah dilanda kekosongan spiritual mengakibakan manusia hidup tanpa makna. Tasawuf sebagai salah satu disiplin ilmu dalam agama Islam dapat menjawab permasalahan spiritualitas manusia modern. Pondok pesantren merupakan lembaga pendidikan Islam yang masih menerapkan pembelajaran tasawuf secara jelas dalam kurikulumnya. Salah satu pesantren yang mengemuka dan menjadikan tasawuf sebagai agenda utama adalah Pondok Pesantren Fajar Dunia. Penelitian ini bertujuan untuk mendeskripsikan dan menganalisis Efektivitas pembelajaran 
Spiritual, Pondok tasawuf dalam mencapai kecerdasan emosional dan spiritual Pesantren di Pondok Pesantren Fajar Dunia. Metode yang digunakan adalah kualitatif. Temuan pada penelitian ini menunjukan bahwa pembelajaran tasawuf yang dilaksanakan di Pondok Pesantren Fajar Dunia berjalan secara efektif, merujuk pada indikator ketercapaian tujuan pembelajaran tasawuf, Proses pengelolaan pembelajaran tawasuf, respon santri terhadap pembelajaran tasawuf dan juga hasil belajar santri.

\section{PENDAHULUAN}

Samsul Munir Amin menukil karya Sayyed Hossen Nasr menyatakan bahwa dunia modern telah dilanda kekosongan spiritual. Kemajuan pesat dalam bidang ilmu pengetahuan, teknologi dan falsafat rasionalisme sejak abad ke-18 tidak mampu memenuhi kebutuhan manusia yang berhubungan dengan nilai-nilai transendental. Terpenuhinyakeinginan yang bersif at materi belum bisa menjawab kebutuhan manusia secara menyeluruh. Ada nilai-nilai dan makna yang belum ditemukan, sehingga tidak merasakan kebahagiaan dalam hidup. Kesenangan yang didapatkan tidak lama akan hilang kembali. Manusia masih mencari-cari kebutuhan vital hidup yang pasti dan benar-benar kekal, dan itu hanya bisa digali dengan spiritualitas ${ }^{1}$. Manusia tidak akan menikmati hidup jika tidak bisa menemukan makna hidup, dan makna hiduphanya bisa didapatkan jika manusia memiliki spiritualitas dalam dirinya.

Menurut Nggermanto dalam Ermi, kecerdasan spiritual dapat membuat individu menjadi manusia secara utuh baik secara intelektual, emosi dan spiritual serta dapat menjadi penghubung diri sendiri dan orang lain. Kecerdasan spiritual membuat manusia lebih mengenal siapa dirinya, apa makna dibalik semua yang terjadi bagi dirinya dan bagaimana dia bisa memberikan tempat dalam dirinya maupun dalam diri orang lain. Dengan kesadaran akan makna tersebutlah akhirnya akan mendidik dan membentuk individu menjadi pribadi yang memiliki budi pekerti yang baik, beretika secara utuh dan dapat menyelesaikan masalahnya dengan baik. Kedua kecerdasan tersebut (emosional dan spiritual) pada dasarnya saling berkaitan satu sama lain. Sebagaimana yang dijelaskan oleh Covey bahwa kecerdasan spiritual dapat

\footnotetext{
${ }^{1}$ Samsul Munir Amin, Ilmu Tasawuf(Jakarta: Amzah, 2014).
} 
membimbing kecerdasan emosi sehingga dapat membuat semuanya berjalan secara sinergis ${ }^{2}$.

Dengan spiritualitas, diyakini bahwa suatu bangsa akan menjadi bangsa yang beradab, negara yang menghargai perbedaan dalam bertoleransi dan rakyat dapat hidup makmur. Dengan spiritualitas juga manusia bisa meraih hal-hal yang tidak berbatas ${ }^{3}$. Tasawuf sebagai salah satu disiplin ilmu dalam agama Islam dapat menjawab permasalahan spiritualitas manusia modern saat ini ${ }^{4}$.

Tasawuf memiliki peranan dan tanggung jawab yang sangat besar dalam spiritualitas seseorang 5 . Tasawuf dapat membentuk kecerdasan spiritual dan akhlak dalam diri manusia ${ }^{6}$. Tasawuf diajarkan di sekolah-sekolah formal sebagai langkah untuk menyempurnakan akhlak dan untuk mencapai kematangan spiritualitas. Ketika manusia terobsesi dengan spiritulitas dan akhlak, maka akan melahirkan sikap yang tenang, senantiasa bersyukur dan dapat menikmati hidupnya meskipun ada banyak masalah yang terjadi ${ }^{7}$. Bertasawuf yang benar berarti merupakan sebuah pendidikan bagi kecerdasan emosional dan spiritual $^{8}$. Dengan demikian, tasawuf sebagai pembelajaran spiritual memiliki tujuan akhir untuk mencapai kecerdasan emosional dan spiritual.

Realitas yang ada menunjukkan adanya reduksi besar-besaran dalam ilmu tasawuf. Ada yang terjebak pada praktiknya dan menganggap bahwa pembelajaran tasawuf hanya sekadar pengamalan zikir. Sehingga dikatakan jika sudah berzikir maka secara otomatis sudah bertasawuf. Selain itu juga, pada praktik uzlah (mengasingkan diri dari kehidupan dunia) yang mana dipahami bahwa seorang sufi harus mengedepankan kehidupan akhirat dan mengesampingkan kehidupan di dunia.

\footnotetext{
${ }^{2}$ Ermi Yantiek, "Kecerdasan Emosi, Kecerdasan Spiritual Dan Perilaku Prososial Remaja," Persona, Jurnal Psikologi Indonesia 3, no. 1 (2014): 22-31.

${ }^{3}$ Saifuddin Aman, Tren Spiritualitas Millenium Ketiga (Banten: RUHAMA, 2013).

${ }^{4}$ DanialLuthfi, "Ta lqin Zikir Sebagai Metode Dakwah," Ilmu Dakwah: Academic Jurnal for Homiletic Studies 11,no. 2(2017): 369-383.

${ }^{5}$ Achmad Husen et a l., "Pendidikan Karakter Berbasis SpiritualismeIslam(Tasawuf)," Jurnal Studi AlQur'an; Membangun Tradisi Berfikir Qur'ami 10, no. 1 (2014): 1-19.

${ }^{6}$ Ainul Ga ni, "Pendidikan Tasawuf Da lam Pembentukan Kecerdasan Spiritual Dan Akhlakul Karimah," Al-Tadzkiyyah: Jurnal Pendidikan Islam 10, no. 2 (2019): 275-286.

${ }^{7}$ Ahmad Muttaqin, "From Occultism to Hybrid Sufism : The Transformation of an Isla mic-Hybrid Spiritual Group in Contemporary Indonesia," IJIMS, Indonesian Journal of Islam and Muslim Societies 4, no. 1 (2014): 81-104.

${ }^{8}$ Husen et a 1., "Pendidikan Karakter Berbasis SpiritualismeIslam (Tasawuf)."
} 
Faktor-faktor yang menyebabkan adanya reduksi dari pembelajaran tasawuf di antaranya: a) Pemahaman guru yang kurang mapan, sehingga tidak bisa menjelaskan secara baik kepada santri. Akibatnya santri tidak bisa memahami tasawuf secara utuh; b) Kebijakan sekolah yang tidak mendukung dilaksanakannya pembelajaran tasawuf; c) Masalah internal santri, berupa melanggar peraturan dengan tidak mengikuti program yang sudah dirancang ${ }^{9}$; serta d) banyak sekali pembelajaran dan pengajaran-pengajaran tasawuf yang tidak terukur indikatornya sehingga hanya terjebak dalam retorika dan wacana.

Pondok pesantren merupakan salah satu lembaga pendidikan Islam yang masih menerapkan pembelajaran tasawuf secara jelas dalam kurikulumnya ${ }^{10}$. Salah satu pesantren yang mengemuka dan menjadikan tasawuf sebagai agenda utama atau pembelajaran utama adalah Pondok Pesantren Fajar Dunia Bogor. Sejak berdirinya, pesantren tersebut memang sudah memiliki visi untuk mengembangkan tasawuf. Dan besar harapan pihak pesantren agar santriny a memiliki kecerdasan secara komprehensif baik itu cerdas spiritual, emosional, sosial, intelektual dan kinestetik. Namun, sampai sejauh ini belum pernah ada penelitian yang membahas apakah pembelajaran tasawuf di pesantren tersebut sudah efektif dalam mencapai tujuan yang diharapkan? Maka dari itu perlu diadakannya sebuah penelitian. Atas dasar itu peneliti tertarik untuk melihat efektivitas pembelajaran tasawuf di Pondok Pesantren Fajar Dunia Bogor.

\section{METODE PENELITIAN}

Penelitian ini menggunakan jenis penelitian kualitatif, yaitu sebuah metode penelitian yang digunakan untuk mendeskripsikan informasi secara lebih detail dan rinci terkait efektivitas pembelajaran tasawuf dalam mencapai kecerdasan emosional dan spiritual di Pondok Pesantren Fajar Dunia Bogor. Metode ini, selain bersifat deskriptif, juga cenderung membutuhkan analisis. Yakni, dengan menganalisis data yang diperoleh dari studi kepustakaan yang terkait dengan penelitian ini, baik melalui buku, jurnal, berita, maupun laporan-laporan hasil kunjungan yang pernah dilakukan di

\footnotetext{
${ }^{9}$ Nur Yasin and Sutiah, "Penerapan Nila i-Nilai Ta sawuf Da lam Pembinaan Akhlak Santri Pada Pondok Pesantren Miftahul Huda Gading Malang," Al-Musannif: Journal of Islamic Education and Teacher Training (Al-Musannif: Jurnal Pendidikan Islam dan Keguruan) 2, no. 1 (2020): 49-68.

${ }^{10}$ Abd. Rahman and Abdul Halim, "Kajian TasawufDi Pesantren (Kajian Terhadap Pemikiran Tasawuf Al-Ghazali)," JPIK: Jurnal Pemikiran dan Ilmu Keislaman 2, no. 1 (2019): 43-58, https://jurnal.instika.ac.id/index.php/jpik/article/view/99/64.
} 
Pondok Pesantren Fajar Dunia Bogor. Data diperoleh dengan teknik pengumpulan data melalui observasi, wawancara dan survei dengan cara menyebarkan angket atau kuesioner kepada 85 santri jenjang SMA di Pondok Pesantren Fajar Dunia Bogor. Dalam menentukan responden peneliti menggunakan teknik random sampling yakni dengan mengambil sampel dalam populasi secara acak.

\section{KAJIAN TEORI}

\section{Efektivitas Pembelajaran}

Supardi mengungkapkan bahwa pembelajaran efektif adalah kombinasi yang baik antara manusia, material, fasilitas, perlengkapan dan prosedur yang mengarahkan perilaku siswa ke arah yang lebih baik dan positif sesuai dengan potensi yang dimiliki siswa dalam mencapai tujuan pembelajaran yang telah ditetapkan ${ }^{11}$. Esti Wuryani dalam Fakhrurrazi mendefinisikan pembelajaran yang efektif adalah proses belajar mengajar yang bukan hanya terfokus pada hasil yang dicapai peserta didik, namun terletak pada kemampuan untuk memberikan pemahaman yang baik, kecerdasan, ketekunan, kesempatan dan mutu serta dapat memberikan perubahan perilaku dan mengaplikasikannyadalam kehidupan siswa ${ }^{12}$. Sedangkan menurut Yusuf Hadi Miarso dalam Tatta Herawati Daulae, pembelajaran yang efektif adalah yang menghasilkan manfaat dan ditujukan kepada para peserta didik melalui penggunaan metode yang tepat. Sehingga,metode pembelajaran yang dipakai dan aktivitas belajar peserta didik akan dijadikan fokus dalam usaha terciptanya efektivitas pembelajaran ${ }^{13}$.

Berdasarkan pengertian menurut para ahli di atas, maka dapat disimpulkan pembelajaran yang efektif adalah pembelajaran yang berlangsung secara aktif dan melibatkan peserta didik, pendidik dan fasilitas serta diperlukannya metode yang tepat dalam proses pembelajaran untuk mencapai tujuan pembelajaran yang telah ditetapkan sehingga mengarahkan pada terjadinya perubahan ke arah yang lebih baik lagi.

Indikator pembelajaran yang ef ektif menurut Yusuf ${ }^{14}$ meliputi; (1) pengelolaan pelaksanaan pembelajaran, (2) proses komunikatif, (3) respon peserta didik, (4)

\footnotetext{
${ }^{11}$ Supardi, Sekolah Efektif, Konsep Dasar Dan Praktiknya. (Jakarta: Rajawali Pers, 2013).

${ }^{12}$ Fakhrurrazi, “Hakikat Pembelajaran Yang Efektif," Jumal At-Tafkir 9, no. 1 (2018): 85-99.

${ }^{13}$ Tatta Herawati Daulae, "Menciptakan Pembelajaran Yang Efektif," Forum Paedagogik 06, no. 02 (2014): 131-150.

${ }^{14}$ Bistari Basuni Yusuf, "Konsep Dan Indikator Pembelajaran Efektif," Jurnal Kajian Pembelajaran dan Keilmuan 1, no. 2 (2018): 13-20.
} 
aktifitas belajar dan (5) hasil belajar. Sedangkan Yusuf Hadi Miarso ${ }^{15}$ mengutip pendapat wotruba and wright menyatakan bahwa ada 7 (tujuh) indikator yang menunjukkan pembelajaran yang efektif, di antaranya; (1) pengorganisasian kuliah dengan baik, (2) komunikasi secara efektif, (3) penguasaan dan antusiasme dalam mata kuliah, (4) sikap positif terhadap mahasiswa, (5) pemberian ujian dan ilai yang adil, (6) keluwesan dalam pendekatan pengajaran dan (7) hasil belajar mahasiswa yang baik. Sementara menurut ${ }^{16}$, model pembelajaran efektif mencakup 4 hal pokok di antaranya; (1) kualitas pembelajaran, (2) tingkat pembelajaran y ang memadai, (3) ganjaran dan (4) waktu.

\section{Pendidikan Tasawuf untuk Pengembangan ESQ}

Menurut Muhammad Musthafa Hilmi yang dikutip oleh Said Aqil Siroj mengemukakan bahwa tasawuf adalah latihan spiritual dan praktik mujahadah yang harus ditempuh oleh seorang salik (orang yang sedang menempuh jalan menuju Allah), laku afeksi dan persaksian atau musyahadah ${ }^{17}$. Sedangkan Imam al-Junaid al-Baghdadi mendefinisikan tasawuf sebagai sifat atau karakter yang melekat pada diri seorang hamba yang sedang menjalani laku asketik-spiritual. Sementara Syaikh Dr. Abdul Halim Mahmud sepakat dengan pendapatnya Abu Bakar al-Kattani,mengemukakan bahwa tasawuf sebagai ash-shafa' wal-musyahadah, yakni satu bentuk pengetahuan tertinggi di bawah kenabian (nubuwwah); ia adalah sebuah musyahadah sekaligus jalan menuju musyahadah tersebut.Dari beberapa pendapat di atas, maka dapat disimpulkan bahwa tasawuf merupakan sebuah perjalanan spiritual menuju kedekatan sedekatdekatnya dengan Tuhan melalui serangkaian proses yang harus dilalui.

Di antara ciri-ciri seseorang yang memiliki kecerdasan emosional dan spiritual dalam dirinya menurut Zohar \& Marshall ${ }^{18}$ adalah: (1) kemampuan bersikap fleksibel (dapat menyesuaikan diri secara spontan dan aktif); (2) memiliki tingkat kesadaran diri yang tinggi; (3) kemampuan untuk menghadapi penderitaan yang sedang dialaminya dan memanfaatkannya ke arah yang positif; (4) kemampuan untuk menghadapi dan melampaui rasa sakit; (5) kualitas hidup yang berorientasi kepada tujuan dan pada nilai-

\footnotetext{
${ }^{15}$ Yusuf Hadi Miarso, Menyemai Benih Teknologi Pendidikan (Jakarta: Kencana, 2007).

16 Punaji Setyosari, "Menciptakan Pembelajaran Yang Efektif Dan Berkualitas," Jurnal Inovasi dan Teknologi Pembelajaran 1, no. 1 (2014): 20-30.

${ }^{17}$ Said Aqil Siroj, Allah Dan Alam Semesta: Perspektif Tasawuf Falsafi (Jakarta: Yayasan Said Aqil Siroj, 2021).

${ }^{18}$ Da nah Zohar and Ian Marshall, SQ Kecerdaan Spiritual (Bandung: Mizan, 2007).
} 
nilai; (6) tidak mengakibatkan kerugian yang tidak perlu terjadi; (7) memiliki pandangan yang luas dalam melihat sesuatu atau keadaan, tidak sempit; (8) memiliki rasa keingintahuan yang tinggi terhadap sesuatu yang belum diketahuinya;(9) memiliki sifat yang bertanggung jawab dan penuh pengabdian.

Ary Ginanjar Agustian mengungkapkan orang yang cerdas adalah orang yang memiliki kecerdasan emosional dan spiritual dalam menjalani kehidupannya seharihari yakni dengan senantiasa berperilaku baik yang tercermin dalam akhlakul karimah. Perilaku yang ditunjukkan seperti istiqomah (konsisten dalam melakukan segala sesuatu), memiliki kerendahan hati (tidak sombong); tawakkal (bersungguh-sungguh dalam berusaha dan berserah diri kepada Allah), keikhlasan (tulus dalam melakukan sesuatu), kaffah (totalitas), tawazun (seimbang), dan ihsan (integritas dan penyempurnaan). ${ }^{19}$

Sementara menurut Hawari ciri-ciri manusia yang memiliki kualitas kecerdasan emosional dan spiritual yang tinggi diantaranya: (1) selalu bersandar kepada ajaran Allah, selalu menjaga perbuatan dan hatinya karena merasa diawasi dan dicatat perbuatannya serta berusaha agar senantiasa berbuat baik. Sikap-sikap ini merupakan wujud dari kepercayaannya terhadap rukun iman; (2) selalu memegang amanah dengan baik dan konsisten karena meyakini bahwa tugas yang diembannya berasal dari Allah, serta selalu berpegang pada amar ma'ruf nahi mungkar sehingga ucapan dan tindakannya selalu mencerminkan nilai-nilai luhur yang sesuai dengan nilai moral dan etika agama; (3) membuat keberadaan dirinya bermanfaat untuk orang lain akibat sikap kepedulian sosialnya yang tinggi. (4) memiliki rasa saling mengasihi dan menyayangi antar sesama sebagai implementasi dari keimanannya. (5) rela berkorban, berbagi dan taat pada tuntunan agama; (6) selalu menghargai waktu dan tidak menyia-nyiakannya dengan cara mengisi waktunya untuk beramal saleh. ${ }^{20}$

\section{KETERCAPAIAN TUJUAN PEMBELAJARAN TASAWUF}

Pengajaran tasawuf di Pondok Pesantren Fajar Dunia lebih kepada ranah praktik karena pihak pesantren percaya bahwa belajar teori tasawuf itu memang penting

\footnotetext{
${ }^{19}$ Ary Gina njar Agustian, Rahasia Sukses Membangun ESQ Power, Sebuah Inner JourneyMelalui Ihsan (Jakarta: Arga, 2008).

${ }^{20}$ Dadang Hawari, Al-Qur'an: Ilmu Kedokteran Jiwa Dan Kesehatan Jiwa (Yogyakarta: Dana Bhakti Prima Yasa, 2004).
} 
sebagai pembuka, tetapi belajar untuk masuk ke dalam praktiknya itu jauh lebih pentin g. Yakni dengan memperbanyakzikir diharapkan akan dapat menghasilkan akhlakyang karimah dalam diri santri. Karena akhlak itu dimulai dari sebuah aksi yang diulangulang, yang mana kekuatan pengulangan itu akan menjadi kebiasaan yang melekat pada diri santri

Pemahaman tentang ilmu Tasawuf merujuk kepada kitab Miftahus Shudur(kunci pembuka dada, alat untuk dzikrullah atau mengingat Allah dan alat untuk membersihkan kalbu) dan ditunjang oleh beberapa kitab lain, yakni kitab Tafrij alKhatir, Tanwirul Qulub, Minahus saniyah, Sirrul Asror, Khozinatul Asror dan Qalaid al Jawahir. ${ }^{21}$ Praktik tasawuf yang dterapkan di lingkungan pondok mewarnai semua mata pelajaran yang ada. Semua pembelajaran yang dilaksanakan berlandaskan pada ruh tasawuf. Tasawuf menjadi hidden kurikulum sesuai dengan kebijakan pesantren.

Pemahaman Tasawuf di Pondok Pesantren Fajar Dunia ditandai dengan penerapan akhlak yang baik dalam kehidupan sehari-hari. Tujuan dari pembelajaran tasawuf di Pondok Pesantren Fajar Dunia Bogor adalah untuk mewarnai sikap d an pola perilaku seluruh warga pondok, agar memiliki akhlak yang mulia selain kompetensi yang mumpuni. ${ }^{22}$ Akhlak yang dimaksud mencakup 3 (tiga) macam akhlak, yakni akhlak kepada Allah, akhlak kepada manusia dan akhlak kepada alam.

Modal utama akhlak kepada Allah adalah dengan mengingat-Nya (Berdzikir) sepanjang waktu, utamanya setelah selesai melaksanakan ibadah shalat fardhu. Dzikir pun dilakukan dengan berbagai variasinya, naik itu tahmid, tahlil, istighfar dan lainlain. Ketercapaian pembelajaran Tasawuf, dibuktikan dengan ketercapaian indikator sebagai berikut,

\section{Taat dalam beribadah dan aktif dalam berzikir}

Berdasarkan hasil pengamatan yang dilakukan, didapatkan bahwa Fajar Dunia memang memiliki komitmen kuat untuk menjadikan santrinya terbiasa melaksanakan shalat fardhu secara berjama' ah dan menyempurnakannya dengan shalat-shalat sunnah. Kesadaran santri Fajar Dunia dalam melaksanakannya cukup tinggi. Di antara shalat

\footnotetext{
${ }^{21}$ Berdasarkan wawancara dengan Ustadz Suparman, Ustdaz yang mengajarkan Tasawuf. Wawancara dilakukan pada tanggal 30 Maret 2021 bertempat di Pondok

22 Berdasarkan wawancara dengan Ustadz Donoyang dilakukan pada tanggal 1 Maret 2021 melalui whatsapp
} 
sunnah yang juga wajib dilaksanakan oleh santri adalah shalat sunnah dhuha, rawatib, awabin, tasbih, lifda'il bala, witr dan tahajjud.

Selain itu juga, Fajar Dunia mendidik santrinya untuk aktif dalam berzikir. Sehingga pihak pesantren membuat jadwal zikir yang harus dibaca oleh santri. Yakni, mendidik santri untuk berzikir dengan lafadz 'laa ilaha illallah' setelah selesai shalat fardhu secara berjama'ah sebanyak minimal 165 kali, ditambah 5.000 kali setiap bulannya.

Selain shalat dan zikir, santri juga dididik untuk menjalankan puasa sunnah senin kamis sebagai latihan dalam mengekang dan agar tidak selalu memperturutkan hawa nafsu.

\section{Mengedepankan sikap berlemah lembut dan tidak melakukan kekerasan} dalam menghadapi sesuatu

Santri Fajar Dunia diharapkan dapat memiliki sikap berlemah lembut terhadap sesamanya dan tidak mudah menghakimi orang lain. Mereka diberikan pemahaman bahwa di dunia luar nanti akan banyak sekali perbedaan-perbedaan yang ada di masyarakat khususnya dalam hal ibadah. Untuk itu pentingnya santri memiliki sikap lemah lembut dan tidak mudah menghakimi orang lain agar dapat hidup rukun dan damai dengan masyarakat yang plural. Untuk memperkuat data yang didapatkan, berikut akan dipaparkan melalui hasil kuesioner di bawah ini:

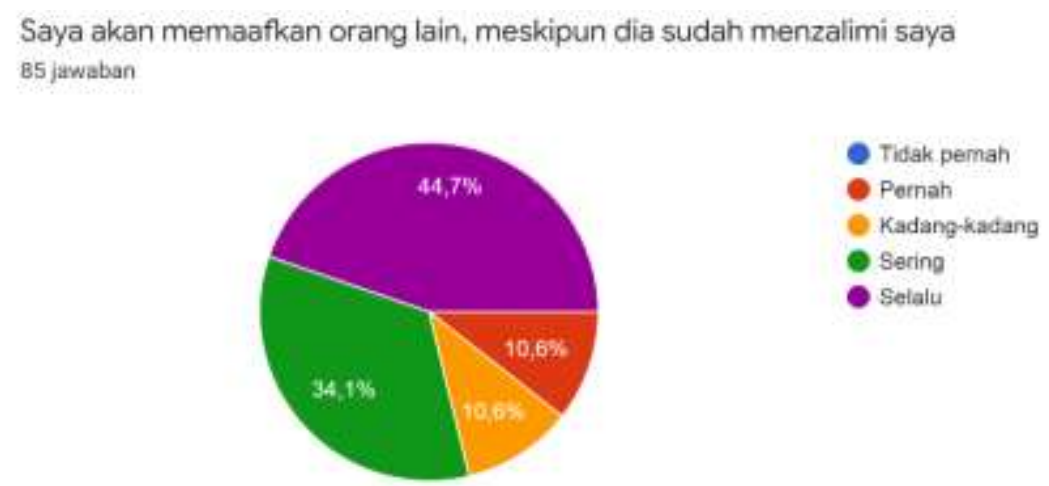

Salah satu sifat kelembutan adalah mudah memaafkan orang lain yang melakukan kesalahan. Jawaban di atas meskipun beragam, tetapi tidak ada yang menjawab tidak pernah. Ini mengindikasikan bahwa santri Fajar Dunia memiliki kelembutan hati yang baik karena mereka mudah memaafkan orang lain yang melakukan kesalahan kepada mereka. Sikap mudah memberikan maaf merupakan sikap 
dasar yang harus dimiliki oleh seseorang yang sedang menempuh jalan menuju Allah, agar hatinya tidak dikotori oleh dendam dan kebencian kepada orang lain.

Manusia cenderung memperlakukan orang lain sebagaimana orang tersebut memperlakukannya. Pernyataan di atas sengaja dimunculkan untuk melihat bagaimana sikap mereka terhadap orang lain yang berkata-kata kasar kepada mereka.
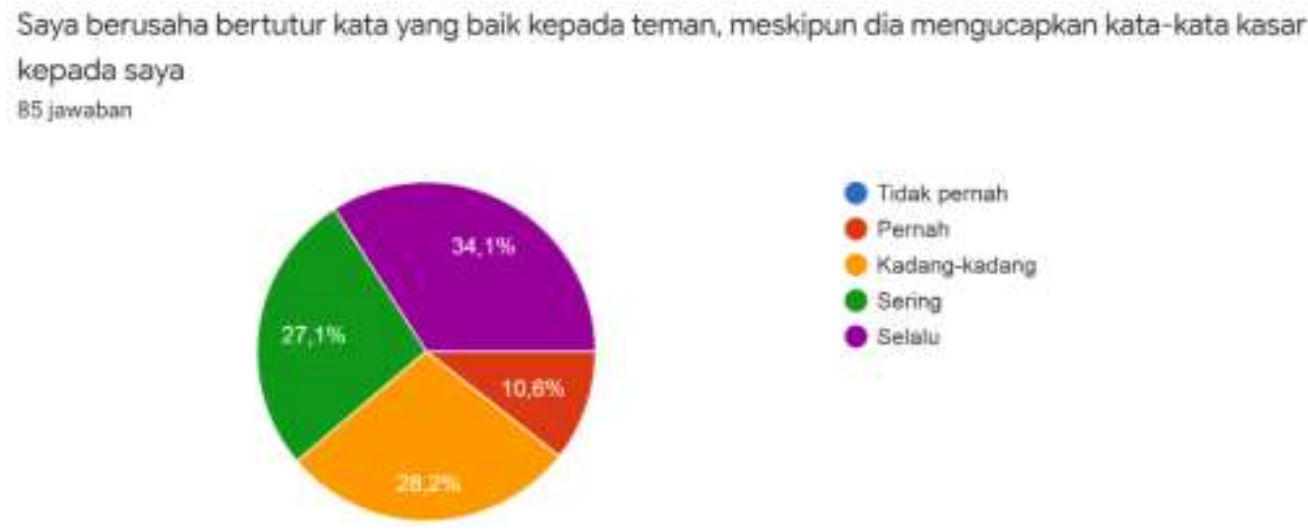

\section{Memiliki kerendahan hati (tidak sombong)}

Seseorang yang mengerti akan keterbatasan dirinya pastilah tidak akan memelihara sifat sombong dalam diri. Ia justru akan membenamkan sifat sombong tersebut. Santri Fajar Dunia diajarkan untuk memiliki kerendahan hati agar jauh dari sifat sombong. Salah satu ciri orang yang memiliki sifat sombong dalam dirinya adalah senang membicarakan kelebihan diri sendiri kepada orang lain. Karena dia merasa hebat dan merasa lebih baik daripada orang lain.

Saat sedang mengobrol, saya membicarakan kelebihan diri sendiri kepada teman saya BS jawaban

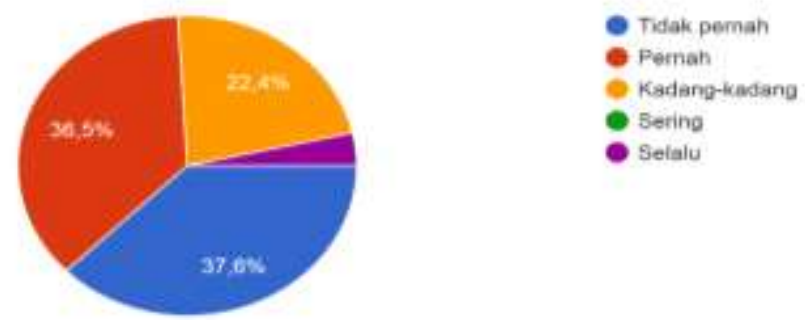

\section{Selalu berpikiran positif}

Berpikiran positif yang dimaksud disini bukan hanya dalam menghadapi persoalan saja, tetapi termasuk juga bersangka baik terhadap diri sendiri dengan cara percaya diri terhadap kemampuan diri sendiri; bersangkabaik kepada orang lain dengan 
cara semua orang dipandang baik sebelum terbukti kesalahan atau kekeliruannya; dan bersangka baik kepada Allah yakni dengan cara berprasangka baik dengan apa yang telah ditakdirkan oleh Allah SWT.

Saya percaya akan ada hikmah di setiap kejadian

B5 jawaban

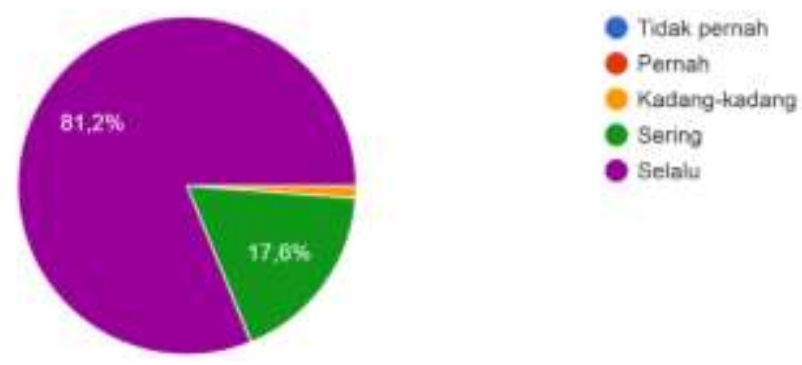

Pernyataan di atas menunjukkan bahwa santri memahami dengan baik bahwa apapun yang terjadi atau apapun yang menimpa dirinya tersimpan hal yang baik meskipun kejadian tersebut terlihat tidak baik secara kasat mata. Dengan demikian santri mempunyai pikiran yang positif terhadap Allah karena dia percaya akan adanya hikmah di setiap kejadian yang menimpa dirinya dan termasuk salah satu takdir Allah yang harus disyukuri.

Saya berbicara hal-hal yang positif pada diri saya B5 jawaban
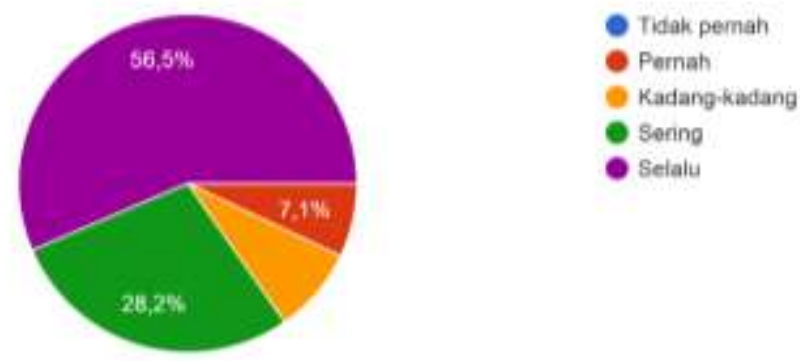

Salah satu indikator seseorang memiliki pikiran yang positif adalah kebiasaannya berbicara hal-hal yang positif pada diri sendiri. Dari pernyataan di atas, menunjukkan bahwa santri memiliki prasangka yang positif terhadap dirinya sendiri karena selalu mensugesti diri dengan hal-hal positif, sehingga secara otomatis akan memunculkan motivasi dan semangat dalam diri.

\section{PROSES PENGELOLAAN PEMBELAJARAN OLEH GURU}

Pembelajaran tasawuf yang dilakukan langsung dibawah bimbingan K.H. Tubagus Abu Arif M. Achsan, Lc., M.Hum selaku pendiri dan pengasuh Pondok Pesantren Fajar Dunia. Namun sepeninggalannya beliau, kemudian dilanjutkan oleh 
Ust. Suparman, M.Pd sebagai orang kepercayaannya pak Kyai dan selaku kepala sekolah SMA Fajar Dunia. Kegiatan pembelajaran dilaksanakan di masjid utama pondok dan dihadiri oleh seluruh santri yang ada.

Penyampaian materi tasawuf dilaksanakan rutin sebulan sekali bersamaan dengan jadwal zikir bulanan dan pembacaan manaqib Syaikh Abdul Qodir. Dalam memberikan penjelasan, Ust. Suparman menggunakan bahasa keseharian sehingga dapat dipahami oleh santri. Mengenai hal ini, berikut akan dipaparkan lebih lanjut melalui hasil kuesioner yang didapatkan:

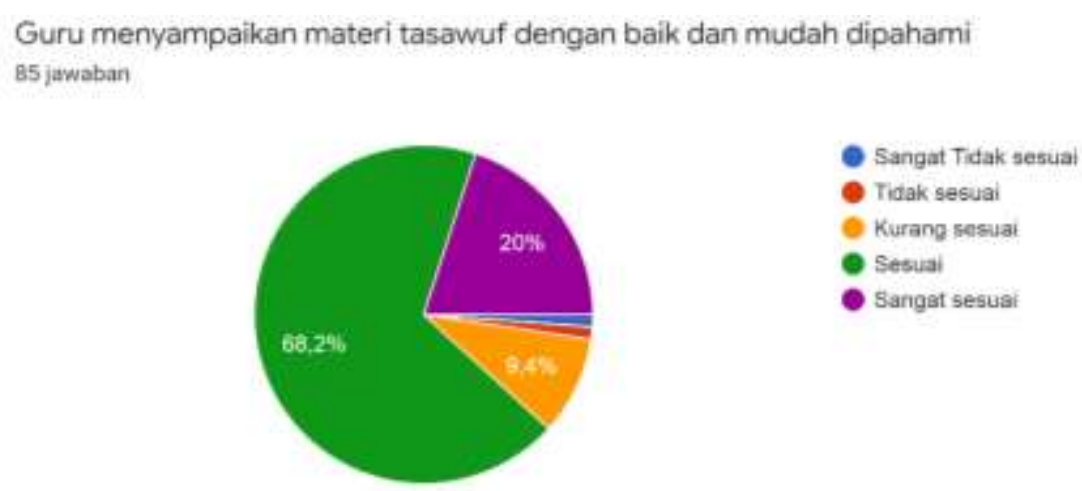

Berdasarkan hasil kuesioner di atas, dapat dipahami bahwa bahasa yang digunakan guru dalam menjelaskan materi pembelajaran khususnya yang terkait dengan tasawuf dapat dipahami dengan baik oleh santri. Meskipun tidak mencapai angka $100 \%$, tetapi sudah mencapai hampir 90\% santri yang dapat memahami penjelasan dari guru.

Metode yang digunakan guru dalam pembelajaran adalah metode ceramah dan diskusi. Terlebih dahulu guru menjelaskan secara detail materi yang disampaikan dan setelah itu dibuka sesi tany a jawab agar santri dapat bertanya tentang materi yang belum dipahaminya. Proses tanya jawabnya juga tidak dilakukan setelah materi ditutup, tetapi saat acara makan bersama. Jadi setelah guru menyampaikan materi langsung di akhiri dan santri mengambil jatah makanan untuk kemudian makan bersama. Saat makan bersama itulah santribisa bertanya kepada Ust. Suparman mengenai materi yang belum dipahami atau untuk menambah wawasannya terkait materi. Menurut Ust. Suparman metode ini dipakai untuk menambah kedekatan dengan santri dan agar santri tidak canggung dalam bertanya sehingga dikemas dengan santai. Untuk memperkuat data yang didapatkan dari wawancara dan observasi berikut akan dijelaskan lebih lanjut 
melalui kuesioner yang dibagikan kepada santri melalui diagram lingkaran di bawah ini:

\section{Metode yang digunakan guru membuat belajar tasawuf menjadi menyenangkan}

85 jawaban

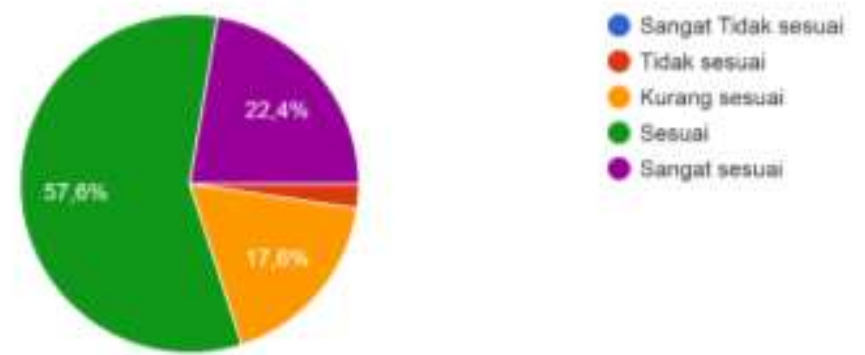

\section{RESPONS SANTRI TERHADAP PROSES PEMBELAJARAN TASAWUF}

Respons santri ketika mendapatkan pembelajaran tasawuf beragam. Awal-awal masuk pesantren adayang belum bisa menerima karena harus men gerjakan serangkaian amalan-amalan dan masih susah dalam mengerjakannya. Hal ini karena latar belakang santri yang berbeda-beda dan cara orang tua mendidik mereka juga berbeda sehingga ada yang membutuhkan waktu untuk beradaptasi dengan sistem pembelajaran yang diterapkan di pondok. Namun, rata-rata setelah melewati fase 6 (enam) bulan tinggal di pondok mereka sudah bisa menerimanya dan mulai melakukan serangkaian amalanamalan tersebut dengan hati yang lapang. ${ }^{23}$ Mengenai respon santri terhadap pembelajaran tasawuf yang dilaksanakan, akan dipaparkan melalui hasil kuesioner berikut ini:

Guru memberikan saya inspirasi dan motivasi ketika belajar tasawuf

85 jawaban
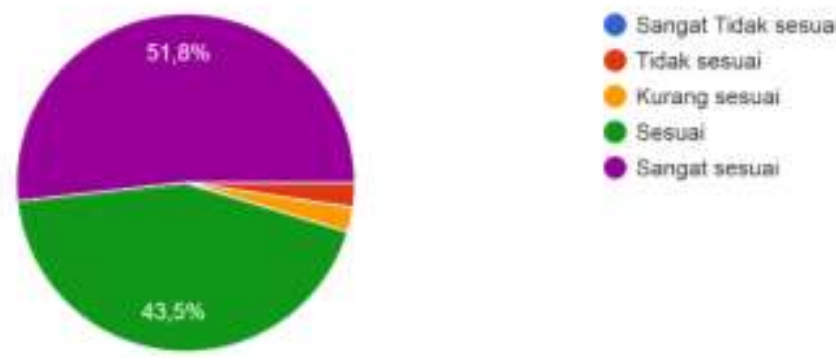

Hasil di atas menunjukkan bahwa santri telah termotivasi untuk mempelajari dan mengamalkan nilai-nilai yang ada dalam tasawuf dalam kehidupannya sehari-hari. Karena setiap pembelajaran tasawuf yang ada selalu mendorong mereka untuk

\footnotetext{
${ }^{23}$ Berdasarkan wawancara dengan Ustadz Suparman, Ustdaz yang mengajarkan Tasawuf. Wawancara dilakukan pada tanggal 31 Maret 2021 bertempat di Pondok
} 
bertasawuf, sehingga seiring dengan berjalannya waktu secara otomatis mereka bisa termotivasi untuk mengamalkannya.

Guru membuat saya antusias ketika belajar tasawuf

85 jawaban
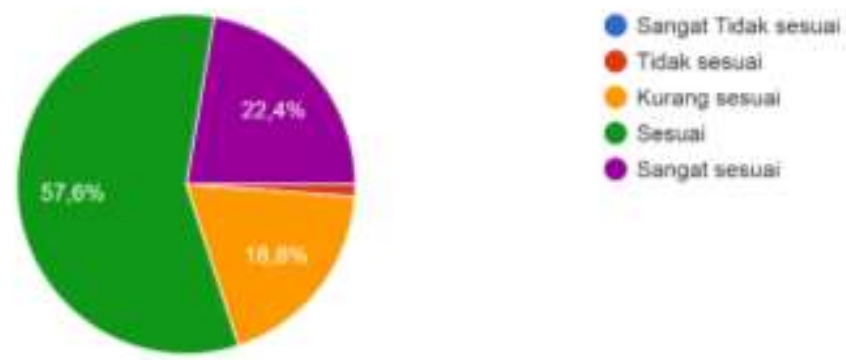

Saya memperhatikan materi tasawuf yang disampaikan guru dengan baik B5 jawaban
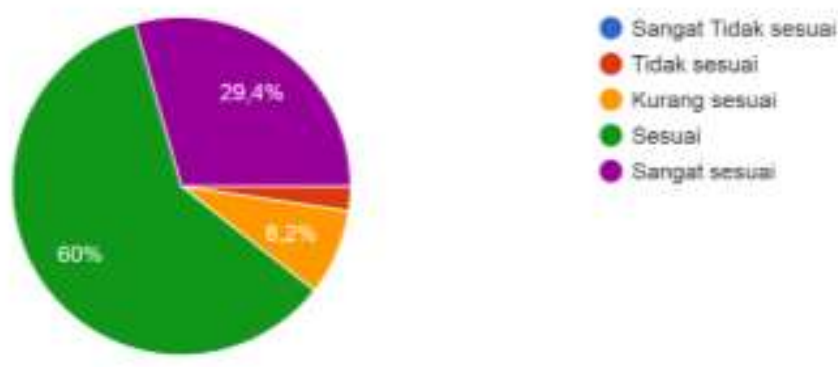

Diagram di atas menunjukkan bahwa guru dapat membuat santri menjadi antusias ketika belajar tasawuf. Antusias disini dalam arti membuat santri menunggununggu waktu belajar tasawuf. Mengingat pembelajaran tasawuf secara teori hanya diadakan satu kali setiap bulannya, sehingga hal ini membuat santri selalu menunggununggu waktu belajar tasawuf. Sepertinya inilah alasan yang mendasari pihak pesantren menjadwalkan pembelajaran tasawuf secara teori hanya satu kali setiap bulannya.

'Diagram di atas mengindikasikan bahwa respon santri terhadap pembelajaran tasawuf sangat baik. karena hampir sebagian besar santri memperhatikan penjelasan yang disampaikan guru saat pembelajaran berlangsung. 


\section{Belajar tasawuf sangat menyenangkan}

86 jawaban

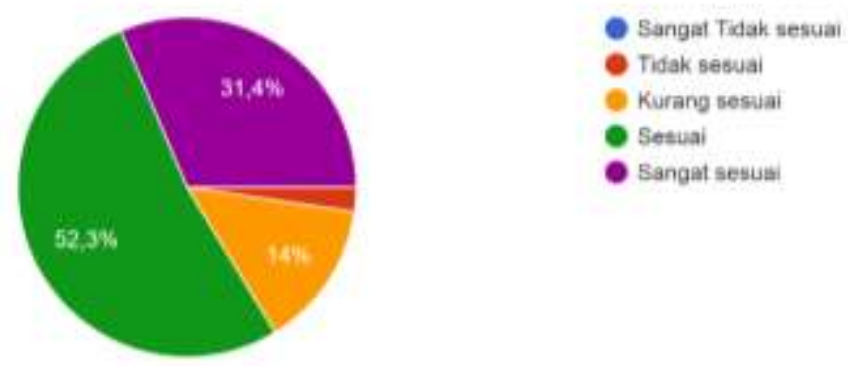

\section{HASIL BELAJAR SANTRI SETELAH MENDAPATKAN PEMBELAJARAN TASAWUF}

Untuk mengukur hasil belajar santri setelah mendapatkan pembelajaran tasawuf di Pondok Pesantren Fajar Dunia, pihak pesantren melihat perilaku dan sikap yang ditunjukkan oleh santri selama di lingkungan pondok. Mengingat pembelajaran tasawuf di Fajar Dunia sebagai pembelajaran akhlak, maka tidak bisa diukur dengan angka. Oleh karena itu, ukuran standar atau sederhana untuk mengukur seorang santri bertasawuf di level dasar yakni dengan melihat perbaikan akhlak sebagai seorang murid. Cara melihat santri sudah bertasawuf atau belu m yakni; (1) saat bertemu orang tua atau guru menunjukkan sikap hormat seperti cium tangan, memberikan salam atau menegur sapa; (2) tutur kata yang disampaikan bagus, atau tidak menyakiti hati; (3) ibadahnya secara syariat bagus, yakni minimal mengikuti semua program pesantren seperti shalat berjama'ah, mengerjakan shalat-shalat sunnah yang ditentukan pondok dan menjalankan puasa sunnah senin kamis.

Ketika ketiga poin di atas sudah ada dalam diri santri, maka santri sudah dikatakan bertasawuf di level dasar. Berdasarkan pengamatan guru dan pihak pesantren paling tidak jika diukur dengan angka maka akan mencapai angka 70\% sampai 80\% dari keseluruhan jumlah santri yang ada, yang telah mempraktikkan tasawuf di level dasar. Tentunya upaya pesantren dalam meningkatkan keberhasilan tersebut tidak pernah berhenti. Lebih lanjut peneliti melihat saat proses penelitian berlangsung, peneliti dibuat takjub dengan akhlak yang dimiliki santri Fajar Dunia. Karena jangankan mencium tangan orang yang lebih tua, bahkan sandal peneliti pun juga diperhatikan oleh mereka. Misalnya, merapihkan sandal orang yang dianggap lebih tua agar bisa langsung dipakai sebagai bentuk ta'zim atau bentuk penghormatan. 


\section{KESIMPULAN}

Berdasarkan hasil dan pembahasan tentang Efektivitas Pembelajaran Tasawuf dalam Mencapai Kecerdasan Emosional dan Spiritual di Pondok Pesantren Fajar Dunia sebagaimana yang telah dipaparkan di atas, maka dapat disimpulkan bahwa pembelajaran tasawuf yang dilaksanakan di Pondok Pesantren Fajar Dunia berjalan secara efektif. Hal ini dilihat dari tercapainya tujuan pembelajaran tasawuf dalam mendidik dan membina akhlak santri, yang dilihat dari sebagian besar santri telah menerapkan nilai-nilai yang diharapkan pihak pesantren seperti: taat dalam beribadah dan aktif dalam berzikir, mengedepankan sikap berlemah lembut dan tidak melakukan kekerasan dalam menghadapi sesuatu, memiliki kerendahan hati (tidak sombong), selalu berpikiran positif.

Kemudian untuk proses pengelolaan pembelajaran oleh guru dilaksanakan dengan baik yang dilihat dari guru menguasai materi dengan baik karena dapat menyampaikan materi dengan bahasa yang mudah dipahami oleh santri, media yang digunakan dapat menunjang pembelajaran, metode yang digunakan dapat membuat pembelajaran menjadi menyenangkan dan pembelajaran berlangsung secara komunikatif. Kemudian untuk respon santri terhadap pembelajaran tasawuf yang dilakukan menunjukkan respon yang baik. Serta hasil belajar santri setelah mendapatkan pembelajaran tasawuf menunjukkan hasil yang sangat baik.

Berdasarkan hasil penelitian yang telah dipaparkan di atas, adapun saran setelah melakukan penelitian ini adalah a) Untuk guru, semoga dapat dijadikan evaluasi dalam proses belajar mengajar tasawuf untuk memperoleh pemahaman dan praktik yang dilakukan santri menjadi lebih baik lagi. Selain itu juga, terkait pelaksanaan pembelajaran yang dilakukan, banyak santri yang mengeluhkan karena dilaksanakan terlalu larut malam. Mereka berharao bisa dilaksanakan lebih awal lagi. b) Untuk sekolah, semoga dapat dijadikan masukan untuk mengembangkan kurikulum tasawuf secara lebih komprehensif sehingga dapat membentuk generasi sufi modern secara lebih maksimal. Termasuk dalam menyiapkan SDM SDM guru yang profesional. c) Untuk pemerintah, semoga dapat dijadikan pertimbangan untuk mengembangkan kebijakan mengintegrasikan tasawuf dalam pembelajaran karakter di sekolah sekolah formal pada umumnya. 


\section{DAFTAR PUSTAKA}

Agustian, Ary Ginanjar. ESQ Emotional Spiritual Quotient: Rahasia Sukses Membangun Kecerdasan Emosi \& Spiritual. Jakarta: PT Arga Tilanta, 2016.

_. Rahasia Sukses Membangun ESQ Power, Sebuah Inner Journey Mela lui Ihsan. Jakarta: Arga, 2008.

Aman, Saifuddin. Tren Spiritualitas Millenium Ketiga. Banten: RUHAMA, 2013.

Amin, Samsul Munir. Ilmu Tasawuf. Jakarta: Amzah, 2014.

Daulae, Tatta Herawati. "Menciptakan Pembelajaran Yang Efektif." Forum Paedagogik 06, no. 02 (2014): 131-150.

Fakhrurrazi. "Hakikat Pembelajaran Yang Efektif." Jurnal At-Tafkir 9, no. 1 (2018): 85-99.

Gani, Ainul. "Pendidikan Tasawuf Dalam Pembentukan Kecerdasan Spiritual Dan Akhlakul Karimah.” Al-Tadzkiyyah: Jurnal Pendidikan Islam 10, no. 2 (2019): 275-286.

Hawari, Dadang. Al-Qur'an: Ilmu Kedokteran Jiwa Dan Kesehatan Jiwa . Yogyakarta: Dana Bhakti Prima Yasa, 2004.

Husen, Achmad, Andy Hadiyanto, Andri Rivelino, and Syamsul Arifin. "Pendidikan Karakter Berbasis Spiritualisme Islam (Tasawuf).” Jurnal Studi Al-Qur'an; Membangun Tradisi Berfikir Qur'ami 10, no. 1 (2014): 1-19.

Luthfi, Danial. “Talqin Zikir Sebagai Metode Dakwah.” Ilmu Dakwah: Academic Jurnalfor Homiletic Studies 11, no. 2 (2017): 369-383.

Miarso, Yusuf Hadi. Menyemai Benih Teknologi Pendidikan. Jakarta: Kencana, 2007. Muttaqin, Ahmad. "From Occultism to Hybrid Sufism: The Transformation of an Islamic-Hybrid Spiritual Group in Contemporary Indonesia." IJIMS, Indonesian Journal of Islam and Muslim Societies 4, no. 1 (2014): 81-104.

Rahman, Abd., and Abdul Halim. "Kajian Tasawuf Di Pesantren (Kajian Terhadap Pemikiran Tasawuf Al-Ghazali).” JPIK: Jurnal Pemikiran dan Ilmu Keislaman 2, no. $\quad 1 \quad$ (2019): https://jurnal.instika.ac.id/index.php/jpik/article/view/99/64.

Setyosari, Punaji. “Menciptakan Pembelajaran Yang Efektif Dan Berkualitas.” Jurnal Inovasi dan Teknologi Pembelajaran 1, no. 1 (2014): 20-30.

Siroj, Said Aqil. Allah Dan Alam Semesta: Perspektif Tasawuf Falsafi. Jakarta: 
Yayasan Said Aqil Siroj, 2021.

Supardi. Sekolah Efektif, Konsep Dasar Dan Praktiknya. Jakarta: Rajawali Pers, 2013. Yantiek, Ermi. “Kecerdasan Emosi, Kecerdasan Spiritual Dan Perilaku Prososial Remaja.” Persona, Jurnal Psikologi Indonesia 3, no. 1 (2014): 22-31.

Yasin, Nur, and Sutiah. "Penerapan Nilai-Nilai Tasawuf Dalam Pembinaan Akhlak Santri Pada Pondok Pesantren Miftahul Huda Gading Malang." Al-Musannif: Journal of Islamic Education and Teacher Training (Al-Musannif: Jurnal Pendidikan Islam dan Keguruan) 2, no. 1 (2020): 49-68.

Yusuf, Bistari Basuni. “Konsep Dan Indikator Pembelajaran Efektif.” Jurnal Kajian Pembelajaran dan Keilmuan 1, no. 2 (2018): 13-20.

Zohar, Danah, and Ian Marshall. SQ Kecerdaan Spiritual. Bandung: Mizan, 2007. 